Bangladesh J. Bot. 48(4): 1107-1113, 2019 (December)

\title{
STANDARDIZATION OF INOCULATION TECHNIQUES FOR SHEATH BLIGHT OF RICE CAUSED BY RHIZOCTONIA SOLANI (KUHN)
}

\author{
Santosh Kumar ${ }^{*}$, Md Nadeem Akhtar ${ }^{1}$, Erayya and Tribhuwan Kumar ${ }^{2}$ \\ Department of Plant Pathology, Bihar Agricultural University, \\ Sabour (Bhagalpur)-813210, Bihar, India
}

Keywords: Rice, Sheath blight, Rhizoctonia solani, Inoculum source, Inoculation

\begin{abstract}
To develop a simple and reliable inoculation technique using inoculum sources viz., mycelial suspension, mycelial ball, sclerotia and soil inoculation with homogenized mycelia suspension was carried out. The efficiency of different inoculation techniques were tested on susceptible rice variety Rejendra Sweta. Sheath inoculation with sclerotia gave lesion length 10.33 and $12.33 \mathrm{~cm}$ after seven and 15 days of inoculation, respectively. It also shows more significance in terms of relative lesion height to plant height i.e. $30.06 \%$ followed by soil inoculation with homogenized mycelial suspension i.e. $21.62 \%$. However, relative number of lesions as compared to control was found to be maximum $(429.18 \%)$ in mycelial suspension spray, followed by soil inoculation using homogenized mycelia suspension $(400.43 \%)$. The disease rating of sheath blight of rice was also found to be maximum (5) in sheath inoculation with sclerotia followed by soil inoculation of mycelial suspension (3). The disease rating was minimum (1) in sheath inoculation with mycelial ball and foliar spray with mycelial suspension.
\end{abstract}

\section{Introduction}

Rice is grown as an important cereal crop all over the world, but extensively grown in southeast Asian countries. Sheath blight of rice, a disease caused by Rhizoctonia solani Kuhn (teleomorph: Thanatephorus cucumeris (A.B. Frank) Donk) has become a most devastating plant pathogen, which causes yield losses up to 54.3\% (Chahal et al. 2003) in rice growing tracts of India. It is considered as one of the most important factors for stagnated productivity of the crop in the country. $R$. solani is soil-borne plant pathogen and has a wide host range, often infecting legume crops grown in rotation with rice (Rush and Lee 1992, Zou et al. 2000). Initially the symptoms appear as water soaked chlorotic patches on leaf sheaths at culms just above the water level which are ellipsoid or ovoid about $10 \mathrm{~mm}$ long somewhat irregular and greenish grey, they enlarge in size and reach $1-3 \mathrm{~cm}$ long with irregular margin. Many different inoculum sources including colonized agar plugs, colonized rice grain or rice straw mixtures blended mycelia, sclerotia has been used in the past for investigating rice sheath blight (Gangopadhyay and Chakraborty 1982, Willocquet et al. 2000, Eizenga 2002). Most of these inoculum sources introduce considerable variability in terms of infection process. Each of these inoculum types has been used by applying different inoculation methods, either in the field or under controlled conditions. In addition, a diversity of inoculum sources and methods used for the analysis of sheath blight resistance, different techniques have been applied for evaluating the severity of disease. The present study has been, undertaken to develop an effective, uniform, and reproducible technique for infecting rice plants with $R$. solani and to improve the accuracy of disease severity evaluation system. This information may be used to devise a simple, less time consuming, precise and reproducible seedling inoculation technique for sheath blight of rice.

*Author for correspondence: <santosh35433@gmail.com>. ${ }^{1}$ KVK, Agwanpur, Saharsa, (Bihar Agricultural University, Sabour) 852 201, Bihar, India. ${ }^{2}$ Department of Molecular Biology and Genetic Engineering (Biotechnology), Bihar Agricultural University, Sabour (Bhagalpur)-813210, Bihar, India. 


\section{Materials and Methods}

The Rhizoctonia solani culture was isolated from the sheath blight infected plant. Seeds of susceptible rice variety Rajendra Sweta were procured from the Department of Genetics and Plant Breeding, Bihar Agricultural University, Sabour. Seeds were sown $\approx 1 \mathrm{~cm}$ deep, in plastic pots (15 $\mathrm{cm}$ diameter) containing partially sterilized soil amended with $30 \mathrm{mg} \mathrm{N}, 9.7 \mathrm{mg} \mathrm{P}$ and $18.5 \mathrm{mg}$ per kilogram of soil as urea, single super phosphate, and murate of potash, respectively. Emerging seedlings were thinned to five per pot. The experiment was conducted in a glasshouse at $26 \pm 3^{\circ} \mathrm{C}$, located in the premises of Mandan Bharti Agriculture College, Agwanpur, Saharsa. A multinucleate compatible $R$. solani isolate of rice, belonging to the AG-1 IA anastomosis group was isolated from the experimental plot by infecting Rajendra Sweta. To compare the effect of inoculum source/inoculation techniques on the severity of sheath blight, inoculation was done at late tillering stage separately, using different inoculation techniques. These were (1) spraying with mycelial suspension: the mycelial suspension was made by homogenizing liquid culture mycelia with a blender having approximately $1.5 \mathrm{~g} / 100 \mathrm{ml}$, (2) sheath inoculation with mycelial ball: three days old culture of $R$. solani was used for the preparation of liquid culture, which was initiated by inoculating $200 \mathrm{ml}$ of potato dextrose broth (PDB) medium in a $250 \mathrm{ml}$ Erlenmeyer flask taking fresh mycelia from PDA. After incubation on a shaker (130 to $140 \mathrm{rpm})$ in dark for 7 to 10 days, liquid cultured mycelia were collected and chopped into small mycelial balls (approx. $0.5 \mathrm{~cm}$ in diameter with a pair of forceps. The mycelial suspension was prepared by homogenizing liquid culture mycelia with a blender (Fig. 1A). After incubation on a shaker (130 to $140 \mathrm{rpm}$ ) under darkness for 7 to 10 days, liquid culture mycelia were harvested and cut into small mycelial balls (approximately $0.5 \mathrm{~cm}$ ) (Fig. 1B), (3) sheath inoculation with sclerotial bodies: six days old mature sclerotial bodies on PDA with size of approximately $3.2 \mathrm{~mm}$ were used as inoculum (Fig.. 1C), (4) soil inoculation with homogenized mycelia suspension: Leaves of typha plant were cut into small pieces and dipped in $5 \%$ glucose and autoclaved at $121^{\circ} \mathrm{C}$. The flask containing bits was inoculated with sclerotia and incubated at $28 \pm 1{ }^{\circ} \mathrm{C}$ for eight days and then used to inoculate soil @ $50 \mathrm{gm} / \mathrm{kg}$ soil (Fig. 1D).

The mycelial ball and sclerotia were inserted beneath the leaf sheath of rice plant, $6-8 \mathrm{~cm}$ above the water level in the experimental pot (Fig. 1E). The inoculated sheath was covered immediately with aluminium foil (Fig. 2A). Pots were covered with moistened polythene bags for maintaining high humidity, $72 \mathrm{hrs}$ thereafter, pots were maintained in a glasshouse at $26 \pm 3^{\circ} \mathrm{C}$ and were regularly examined for symptom appearance (Fig. 1F). When typical lesions/symptoms appeared after six days (Fig 2B), the aluminium foil was removed. The pots were watered regularly to ensure proper humidity.

Sheath blight severity, the lesion length and the degree of disease severity were recorded from each sheath of inoculated plants. Observations were recorded as relative number of lesions/plant (unit), relative lesion height to plant height (\%) at eight days after inoculation, per cent disease severity after seven and 15 days of inoculation and per cent disease incidence. Three replications (culms) were maintained for each inoculum type in the inoculation study. The sheath blight disease severity was also analysed and expressed in disease rating scale of 0 - 9 (based on relative lesion height to plant height) as per standard evaluation system for rice (Ahn and Mew 1986) (Fig. 3 and Table 1).

Relative lesion height was calculated using the following formula:

Relative lesion height $(\%)=\frac{\text { Total lesion length }}{\text { Plant height }} \times 100$ 
Table 1. Disease rating scale for sheath blight of rice (Ahn and Mew` 1986).

\begin{tabular}{ll}
\hline Disease rating scale & Relative lesion height to plant height (\%) \\
\hline 0 & No infection observed \\
1 & Lesions limited to lower 20\% of the plant height \\
3 & $20-30$ \\
5 & $31-45$ \\
7 & $46-65$ \\
9 & More than 65 \\
\hline
\end{tabular}

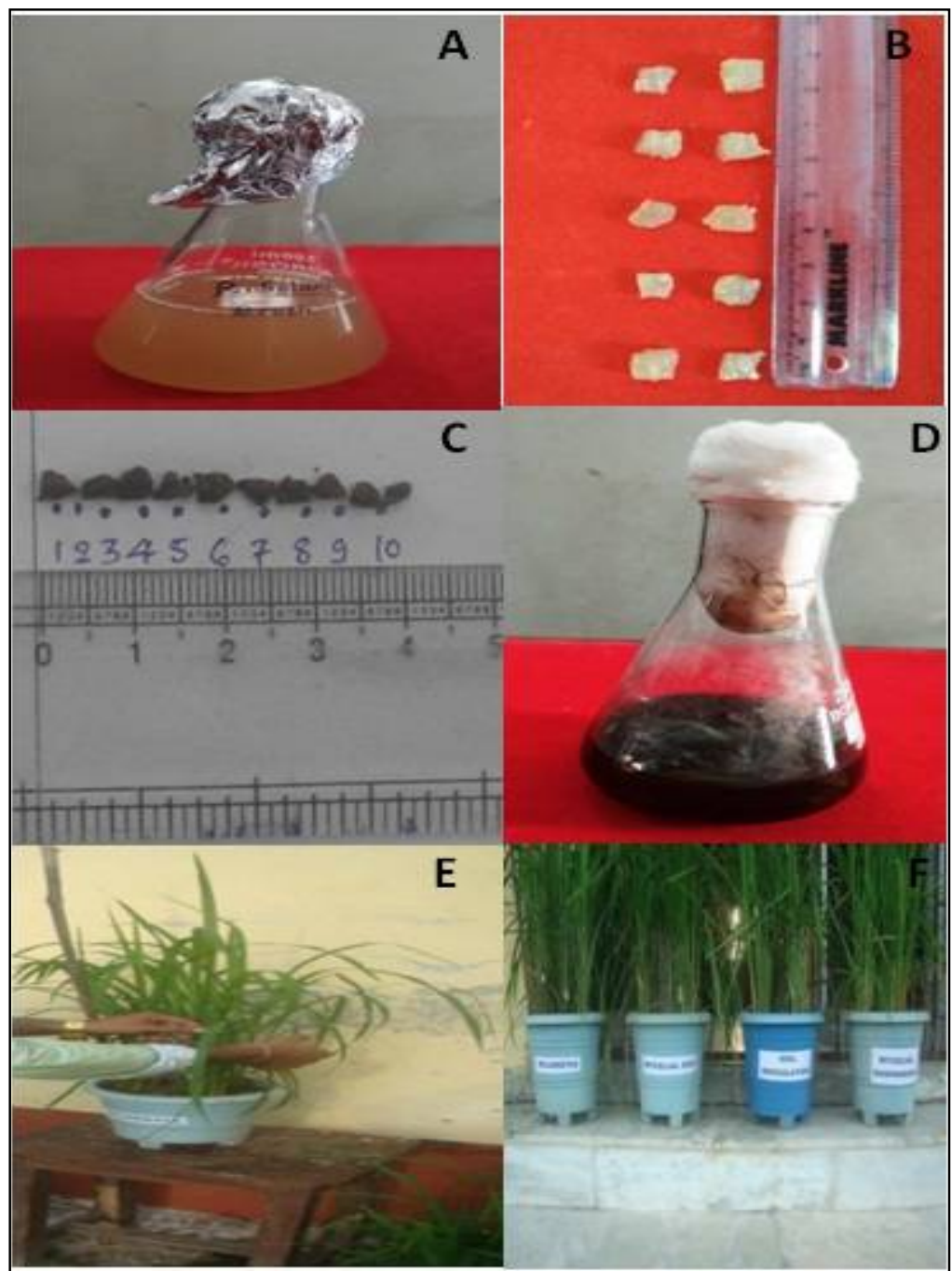

Fig. 1. Inoculum preparation and inoculation of $R$. solani. (A) $R$. solani growth in potato dextrose broth. (B) Mycelial mycelial balls of $R$. solani. (C) Sclerotia harvested from culture plate for inoculation. (D) Homogenised mycelial suspension. (E) Inoculation of pathogen to the test plant and (F) pot culture of inoculated plants in glass house. 

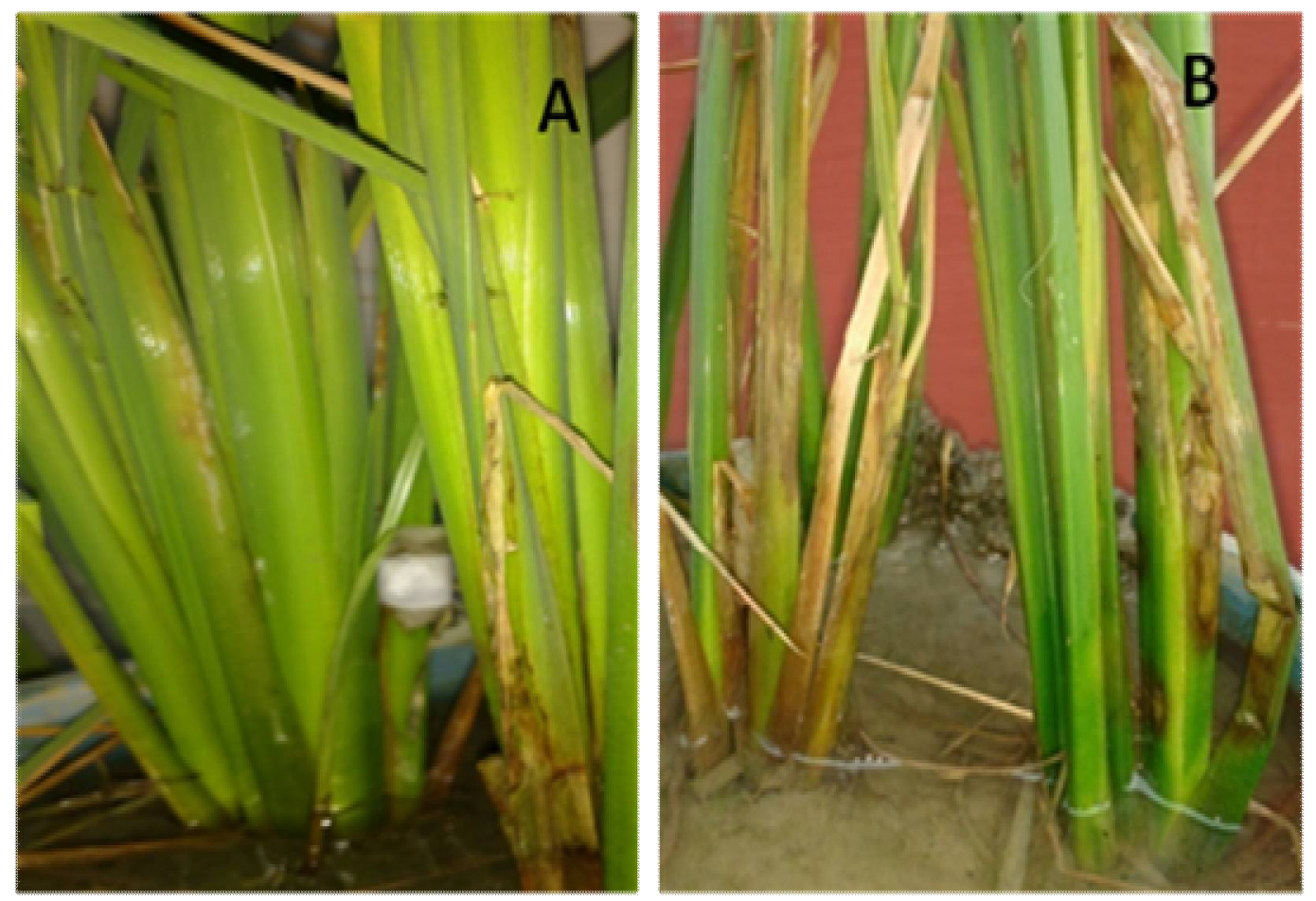

Fig. 2(A). Inoculated sheath covered with aluminium foil. (B) Appearance of disease symptoms on sheath at six days after inoculation.

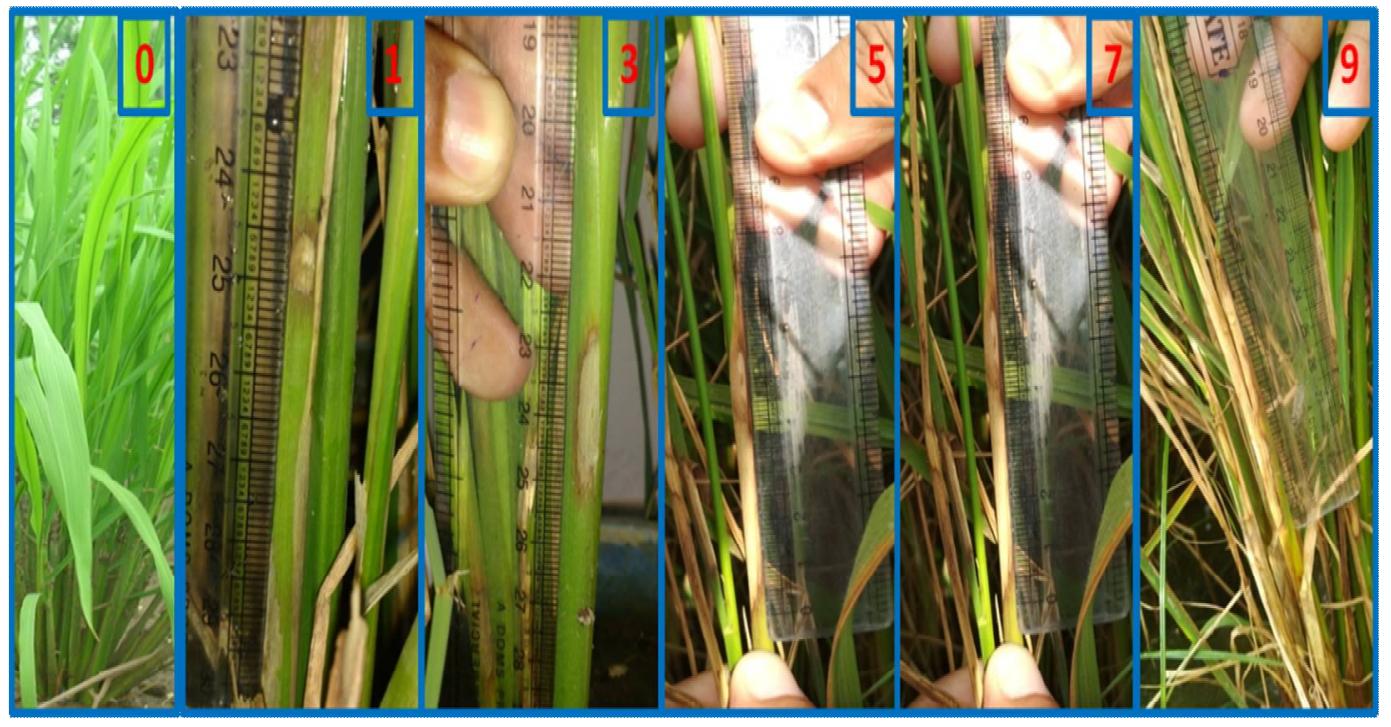

Fig. 3. Disease rating scale for sheath blight of rice. 


\section{Results and Discussion}

An effective inoculation technique is a critical component for any decisive disease assay leading to quantify the of level of sheath blight resistance in rice cultivars. The type of inoculum used for inoculation is a critical determinant for any infection efficiency. Among many inculcation methods ascertained for sheath blight of rice, the sclerotial inoculation (sheath) technique was found more significant with respect to lesion height to plant height i.e. $30.06 \%$ followed by soil inoculation with homogenized mycelial suspension i.e. 21.62\% (Table 2). However, minimum relative lesion height to plant height $(16.37 \%)$ was observed when plants were sprayed with mycelial suspension.

Table 2. Relationship between different inoculation techniques and lesion height.

\begin{tabular}{lllll}
\hline $\begin{array}{l}\text { Inoculum } \\
\text { source }\end{array}$ & $\begin{array}{l}\text { Plant height } \\
(\mathrm{cm})\end{array}$ & $\begin{array}{l}\text { Lesion height } \\
(\mathrm{cm})\end{array}$ & $\begin{array}{l}\text { Relative lesion height } \\
\text { to plant height }(\%)\end{array}$ & $\begin{array}{l}\text { Disease } \\
\text { rating scale }\end{array}$ \\
\hline 1. Mycelial suspension & 61.56 & 10.08 & 16.37 & 1 \\
2. Mycelial ball & 70.17 & 13.17 & 18.77 & 1 \\
3. Sclerotia & 78.10 & 23.48 & 30.06 & 5 \\
4. Soil inoculation using & 76.72 & 16.59 & 21.62 & 3 \\
homogenized mycelia suspension & & & & \\
5. Control & 80.19 & 5.10 & 6.36 & \\
CD (p=0.05) & 2.98 & 1.53 & 2.01 & \\
CV $(\%)$ & 2.20 & 6.07 & 5.85 & \\
\hline
\end{tabular}

*The observations recorded in present study are average of five plants and three replications.

This finding is also somewhat similar to the report of Singh et al. 2001 where smaller and young sclerotia infect plants more quickly than mature sclerotia. Park et al. 2008 also reported that mycelial suspensions were the least efficient inoculation source, possibly because the mycelium break apart, preventing the allocation of nutrients through the mycelial network to the point of infection. Present finding is also evidenced Sunder et al. 2003 who found that vertical spread of the disease was maximum when inoculation was done with inoculum grown on a mixture of rice grains + barley grains + typha pieces $(1: 1: 1)$ followed by inoculation with sclerotia. De Silva et al. (1985) had also reported that grain medium supported maximum growth of sclerotia and resulted well when inoculated $R$. solani under field condition. The disease severity was also analysed and expressed in disease rating scale. The disease rating of sheath blight of rice was also found maximum (5) in sclerotial inoculation followed by soil inoculation using homogenized mycelia suspension (3). However, the disease rating was minimum (1) in case of both mycelial ball and suspension inoculation methods.

Relative number of lesions and their length were analyzed with respect to control and expressed in percentage (Table 3). Relative number of lesions as compared to control was found maximum (429.18\%) in mycelial suspension spray, followed by soil inoculation using homogenized mycelia suspension $(400.43 \%)$. However, the minimum $(185.84 \%)$ relative number of lesions to control was recorded in mycelial ball inoculation. The relative length of lesion was assessed after seven and 15 days of inoculation. The maximum length of lesion observed in sclerotial inoculation method was $281.48 \%$ after seven days and $290.12 \%$ after 15 days followed by soil inoculation using homogenized mycelia suspension i.e. 199.73 and $227.53 \%$, respectively. However, the minimum relative lesion length i.e. 163.48 (seven days) and $180.47 \%$ (15 days) appeared when it was done with foliar spray of mycelial suspension. 
Table 3. Relationship of different inoculation techniques with number of lesion and lesion length.

\begin{tabular}{|c|c|c|c|c|c|c|}
\hline $\begin{array}{l}\text { Inoculum } \\
\text { source }\end{array}$ & $\begin{array}{l}\text { Average } \\
\text { no. of } \\
\text { lesions/ } \\
\text { plant }\end{array}$ & $\begin{array}{l}\text { Relative no. } \\
\text { of lesions to } \\
\text { control } \\
(\%)\end{array}$ & $\begin{array}{c}\text { Average length } \\
\text { of lesion after } 7 \\
\text { days of } \\
\text { inoculation } \\
(\mathrm{cm})\end{array}$ & $\begin{array}{c}\text { Relative } \\
\text { lesion } \\
\text { length } \\
\text { to control } \\
(\%)\end{array}$ & $\begin{array}{c}\text { Average length } \\
\text { of lesion after } \\
15 \text { days of } \\
\text { inoculation } \\
(\mathrm{cm})\end{array}$ & $\begin{array}{l}\text { Relative } \\
\text { lesion } \\
\text { length to } \\
\text { control } \\
(\%)\end{array}$ \\
\hline $\begin{array}{l}\text { 1. Mycelial } \\
\text { suspension }\end{array}$ & 10.00 & 429.18 & 6.00 & 163.48 & 7.67 & 180.47 \\
\hline 2. Mycelial ball & 4.33 & 185.84 & 6.33 & 172.48 & 8.33 & 196.00 \\
\hline 3. Sclerotia & 6.00 & 257.51 & 10.33 & 281.48 & 12.33 & 290.12 \\
\hline $\begin{array}{l}\text { 4. Soil } \\
\text { inoculation } \\
\text { using } \\
\text { homogenized } \\
\text { mycelia } \\
\text { suspension }\end{array}$ & 9.33 & 400.43 & 7.33 & 199.73 & 9.67 & 227.53 \\
\hline 5. Control & 2.33 & 100.00 & 3.67 & 100.00 & 4.25 & 100.00 \\
\hline $\mathrm{CD}(\mathrm{p}=0.05)$ & 2.97 & & 0.752 & & 0.70 & \\
\hline
\end{tabular}

The suitability of inoculation method varies with pathogen and host. Such as spore suspension inoculation method was found suitable in case of Alternaria brassicae on mustard (Giri et al. 2013). Similarly the leaf sheath inoculation method was suitable for screening sorghum against sheath blight (Cecilia and Avelino 1988). Chona et al. (1961) reported that boot leaf inoculation with sporidial suspension of Neovosia indica as a best method for bunt of wheat. The per cent infection of Melanopsichium eleusinis on ragi was more when young inflorescence was sprayed with the sporidial suspension (Ganapathi 1971). Boot leaf inoculation with sporidial suspension of smut fungus to pearl millet showed maximum disease severity than other methods employed (Mitter and Siddiqui 1997). Approximately $0.2 \mathrm{mg}$ of inoculum placed inside the leaf sheath with a few drops of sterile water invariably induced single discrete, uniform-sized lesions (Singh et al. 2002). Sunder et al. (2003) also found that vertical spread of sheath blight was maximum when inoculation was done with inoculum grown on a mixture of rice grains + barley grains + typha pieces $(1: 1: 1)$ followed by inoculation with sclerotia. Park et al. (2008) were reported that liquid cultured mycelial balls caused significantly longer lesions than other types of inoculums. Singh et al. (2010) were also observed the maximum sheath blight incidence on rice seedlings inoculated with the mycelia inoculum raised on barley grains. But in our case, sheath inoculation with sclerotia is the most suitable methods to inoculate rice plant in order to study the pathogenicity, disease incidence and severity, and screening rice germplasm against sheath blight. However, there is a vast diversity in life cycle, inoculums type and inoculums potential among the plant pathogenic fungi which limit the suitability of different inoculation methods on different host crops.

Selection of sheath blight resistant cultivar/s of rice is the most economic and eco-friendly way of cultivation. Hence, uniform and effective inoculation and accurate evaluation methods are required for genetic, molecular, biochemical, functional genomics analyses and for measuring quantitative differences in sheath blight resistant rice varieties/germplasm. Sheath inoculation with sclerotial bodies has been proven as most efficient, highly consistent and reproducible inoculation method for sheath blight pathogen in this study. The results may be used for accurate measurement of disease severity, screening rice germplasm and identification of new races of pathogen. 


\section{Acknowledgments}

Authors acknowledge the financial and technical support of Directorate of Research, Bihar Agricultural University, Sabour to undertake this study. Associate Director Research, Regional Research Station, Agwanpur, Saharsa is also acknowledged for his kind support and execution of this research programme. This manuscript bears BAU communication No. 305/2017.

\section{References}

Ahn SW and Mew TW 1986. Relation between rice sheath blight and yield. International Rice. Res. Newsl. 11: $21-22$.

Cecilia BP and Avelino DR 1988. Evaluation of resistance and yield loss in sorghum due to Rhizoctonia sheath blight. Philipp. J. Crop Sci. 13(1): 37-42.

Chahal SS, Sokhi, SS and Ratan GS 2003. Investigation on sheath blight of rice in Punjab. Indian Phytopath. 56: $22-26$.

Chona BL, Munjal RL and Adlakha KL 1961. A method for screening wheat plants for resistance to Neovosia indica. Indian Phytopath. 14: 99-101.

De Silva YJPA and Adikari WP 1985. A method for producing Rhizoctonia solani inoculums for field inoculation. Intern. Rice. Res. Newsl. 10: 18-19.

Eizenga GC, Lee FN and Rutger JN 2002. Screening Oryza species plants for rice sheath blight resistance. Plant Dis. 86: 808-812.

Ganapathi TK 1971. Studies on the biology of smut disease of Eleusine coracana Gaertn. (finger millet) caused by Melanopsichium eleusinis (Kulk.) Mundk and Thirum. M.sc. (Agri.) Thesis, University of Agriculture Sciences, Bangalore, India, pp 49.

Gangopadhyay S and Chakraborty N 1982. Sheath blight of rice. Rev. Plant Pathol. 61: 451-455.

Giri P, Taj G and Kumar A 2013. Comparison of artificial inoculation methods for studying pathogenesis of Alternaria brassicae (Berk.) Sacc on Brassica juncea (L.) Czern. (Indian mustard). African J. Biotechnology 12 (18): 2422-2426.

Mitter V and Siddiqui MR 1997. Inoculation method for pearl millet smut. J. Mycol. Pl. Pathol. 27(2): 188190.

Park DS, Sayler RJ, Hong YG, Nam MH and Yang Y 2008. A method for inoculation and evaluation of rice sheath blight disease. Plant Dis. 92: 25-29.

Rush MC and Lee FN 1992. Sheath blight. In: Compendium of Rice Diseases. RK Webster and PS Gunnell, eds. The American Phytopathology Society, St. Paul, MN. PP 22-23.

Singh A, Rohilla R, Singh US, Savary S, Willocquet L and Duveiller E 2002. An improved inoculation technique for sheath blight of rice caused by Rhizoctonia solani. Canadian J. Plant Pathol. 24: 65-68.

Singh R, Sunder S and Dodan DS 2010. Standardization of inoculation method in nursery beds and management of sheath blight of rice through host resistance, chemicals and botanicals. Indian Phytopath. 63: 286-291.

Sunder S, Singh R and Dodan DS 2003. Standardization of inoculation methods and management of sheath blight of rice. Indian J. Pl. Pathol. 21: 92-96.

Willocquet L, Fernandez L and Savary S 2000. Effect of various crop establishment methods practiced by Asian farmers on epidemics of rice sheath blight caused by Rhizoctonia solani. Plant Pathol. 49: 346-354.

Zou JH, Pan XB, Chen ZX, Xu JY, Lu JF, Zhai WX and Zhu LH 2000. Mapping quantitative trait loci controlling sheath blight resistance in two rice cultivars (Oryza sativa L.). Theor. Appl. Genet. 101: 569-573.

(Manuscript received on 15 September, 2018; revised on 19 January, 2019) 